\title{
デサリネーション適用後の鉄筋防食効果に関する研究
}

\author{
上田 隆 雄* 芦田公 伸**宮 川 豊 章***
}

\section{Corrosion Protection Behavior of Reinforcing Steel after Desalination on Concrete Structure}

\author{
by
}

\author{
Takao UedA ${ }^{*}$, Masanobu AshidA ${ }^{* *}$ and Toyoaki Mryagawa ${ }^{* * *}$
}

\begin{abstract}
Desalination is one of the electrochemical methods, aiming to remove chlorides from reinforced concrete structures. However, it is impossible to extract all of chlorides contained in concrete. For this reason, it is important to improve the chloride removal efficiency and to estimate the durability of structures after treatment.

In this study, distribution of $\mathrm{Cl}^{-}$(total chlorides and water soluble chlorides) was examined after applying desalination. The effect of discontinuous treatment was also investigated. Secondly, change of half cell potential and polarization resistance with time were measured after desalination.

The results showed that the steel protection effect due to applying desalination had been maintained for long time. However, in this study, it was difficult to improve chloride removal efficiency by means of intermittent treatment. So, measuring of half cell potential and polarization resistance is useful to monitor the steel condition after treatment.
\end{abstract}

Key words : Desalination, Electrochemical repair method, Chloride removal, Intermittent treatment, Half cell potential, Polarization resistance, Durability after desalination

\section{1 は じめに}

近年，塩害や中性化により劣化したコンクリート構造 物の補修工法として，電気化学的な手法が注目されてい る、デサリネーションはコンクリート中の塩化物イオン $\left(\mathrm{Cl}^{-}\right)$の除去を目的とする電気化学的手法であり，電気 防食の 100 倍近い電流を用いるものの，一定期間の通電 処理で完了するという特色を有している。コンクリート 中の鉄筋を陰極とし，コンクリート表面に設置した陽極 との間に直流電流が流されることにより， $\mathrm{Cl}^{-}$や $\mathrm{OH}^{-}$な どの陰イオンは陽極方向に移動し, $\mathrm{Na}^{+}$や $\mathrm{K}^{+}$などの陽イ オンは陰極近傍に移動・集積する.

デサリネーションにおける通電処理は一定期間のみで あり, 処理終了後は最小限のモニタリング以外は必要無 いはずである。しかし，デサリネーションによって除去 される $\mathrm{Cl}^{-}$は基本的にイオンの形で遊離した $\mathrm{Cl}^{-}$であり, Friedel 氏塩等の形で固定されている $\mathrm{Cl}^{-}$，および輸率の 低下等によって除去されなかった $\mathrm{Cl}^{-}$がコンクリート中， 特にコンクリート表面付近に残存することが報告されて いる. . このような $\mathrm{Cl}^{-}$の処理後の挙動によっては，鉄筋 腐食が再発する可能性が考えられることから，デサリネ ーションによる脱塩効果の的確な把握と, 処理後の長期 耐久性の評価が求められている.

そこで本研究では，あらかじめ $\mathrm{Cl}^{-}$を混入した供試体 に通電処理を行ったときの, 脱塩効果を検討するととも に，処理後の鉄筋防食効果を電気化学的特性值を用いて
評価することを目的とした，なお，従来からの連続的な 通電処理に加えて，断続的な通電処理を行うことによる 脱塩効果の変化についても併せて検討を行った。

\section{2 実 験 概 要}

実験は，デサリネーションを適用した鉄筋コンクリー 卜供試体を用いた，化学分析（全塩分濃度分布測定およ び可溶性塩分濃度分布測定)，鉄筋自然電位の経時変化 測定および分極抵抗の経時変化測定からなる。これらの 概要を Table I に示す。なお，ここで示した電流密度の 值は鉄筋表面積に対する値である.

\section{$2 \cdot 1$ 供試体の作成}

本研究で作成した供試体は, 1 辺が $10 \mathrm{~cm}$ の立方体コ ンクリートの中央部分に異形鉄筋 D13 SD295Aを1本 配したものとした。

コンクリートの示方配合を Table II に示す.コンクリ 一ト中にあらかじめ混入する $\mathrm{Cl}^{-}$量としては，比較的厳 しい塩害が生じた場合に見られる, $8.0 \mathrm{~kg} / \mathrm{m}^{3}$ と 4.0 $\mathrm{kg} / \mathrm{m}^{3}$ を選んだ。セメントは普通ポルトランドセメント を用い，練り混ぜ時に混入する塩化物は精製塩（ $\mathrm{NaCl}$, 純度 99\%）を用いた。なお，塩化物の混入時には同質量 の細骨材を減ずることとした。

\section{$2 \cdot 2$ 通電方法}

供試体はコンクリート打設後 1 日で脱型した後, 密封 状態で 28 日間の湿空養生を行った。この後に，通電処 理を行う供試体については陽極を設置し，電解液中で電

$\dagger \quad$ 原稿受理 平成 10 年 9 月 24 日 Received Sep. 24,1998

* 正会員 徳島大学工学部建設工学科，F770-8506 徳島市南常三島町, Dept. of Civil Eng., Tokushima Univ., Minamijosanshima-cho, Tokushima, 770-8506

** 正 会 員 電気化学工業(㑣セメント特混研究所 †949-0305 新潟県西頸城郡青海町, Denki Kagaku Kogyo Co. Ltd., Nishikubiki-gun, Niigata, 949-0305

*** 正 会 員 京都大学大学院工学研究科土木工学専攻 ７606-8501 京都市左京区吉田本町, Dept. of Civil Eng., Kyoto Univ., Sakyo-ku, Kyoto, 606-8501 
Table I. Outline of test program.

\begin{tabular}{c|c|c|c|c}
\hline $\begin{array}{c}\text { Amount of } \mathrm{Cl}^{-} \\
\left(\mathrm{kg} / \mathrm{m}^{3}\right)\end{array}$ & \multicolumn{2}{|c|}{4.0} & \multicolumn{2}{|c}{8.0} \\
\hline $\begin{array}{c}\text { Current density } \\
\left(\mathrm{A} / \mathrm{m}^{2}\right)\end{array}$ & 0.0 & 5.0 & 0.0 & 5.0 \\
\hline $\begin{array}{c}\text { Period of treatment } \\
\text { (weeks) }\end{array}$ & \multicolumn{3}{|c}{8 (including discontinuous treatment) } \\
\hline $\begin{array}{c}\text { Measurements } \\
\text { after treatment }\end{array}$ & $\begin{array}{l}\text { - Total chlorides and water soluble } \\
\text { chlorides distribution) } \\
\text { Half cell potential } \\
\text { Polarization resistance }\end{array}$ \\
\hline
\end{tabular}

Table II. Mix proportion of concrete.

\begin{tabular}{c|c|c|c|c|c|c|c|c}
\hline W/C & s/a & NMS & \multicolumn{6}{|c}{ Unit mass $\left(\mathrm{kg} / \mathrm{m}^{3}\right)$} \\
\cline { 4 - 9 }$(\%)$ & $(\%)$ & $(\mathrm{mm})$ & $\mathrm{W}$ & $\mathrm{C}$ & $\mathrm{S}$ & $\mathrm{G}$ & $\mathrm{AEA}$ & $\mathrm{WRA}$ \\
\hline 54 & 45 & 13 & 177 & 328 & 801 & 988 & 0.82 & 1.8 \\
\hline
\end{tabular}

流を流した．陽極は白金メッキチタンメッシュを用い， 電解溶液は飽和 $\mathrm{Ca}(\mathrm{OH})_{2}$ を用いた。通電面は向かい合う 2 側面とし，電流を流さない面はエポキシ樹脂を塗り， 絶縁した (Fig. 1参照)。また, 無通電の供試体も処理 期間中（養生終了後 8 週間）は電解溶液中に保存した.

電流密度は，デサリネーションで従来しばしば用いら れている, コンクリート表面に対して $1.0 \mathrm{~A} / \mathrm{m}^{2}$ を基本と した。これは，今回の実験に打いては鉄筋表面積に対し て $5.0 \mathrm{~A} / \mathrm{m}^{2}$ となった。

通電期間は 8 週間連続通電を基本とした。断続通電を 行う場合には, 4 週間連続通電を行った後に, 10 週間の 湿空静置期間または 20 週間の促進中性化期間を設け, その後に再度 4 週間連続通電を行って, 全体で 8 週間の

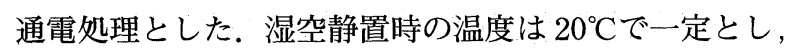
湿度は $95 \%$ 以上で密封した。促進中性化の条件は, 温度 $30^{\circ} \mathrm{C}$, 湿度 $95 \%, \mathrm{CO}_{2}$ 濃度 $5.0 \%$ とした。

\section{$2 \cdot 3$ 処理後の静置条件}

処理後の静置条件としては, 室内静置 (温度 $20^{\circ} \mathrm{C}$, 湿 度 $70 \%$ ） と塩水（5.0\%の $\mathrm{NaCl}$ 溶液）への浸漬の 2 条件 を設定した．塩水に浸漬する際には，鉄筋の出ている供 試体上面を塩水面上とすることにより, 空気中からの酸 素の供給が可能な状態とした。

8 週間処理後の静置を行っている供試体に対して, 鉄 筋の自然電位抢よび分極抵抗の経時変化を測定した．照

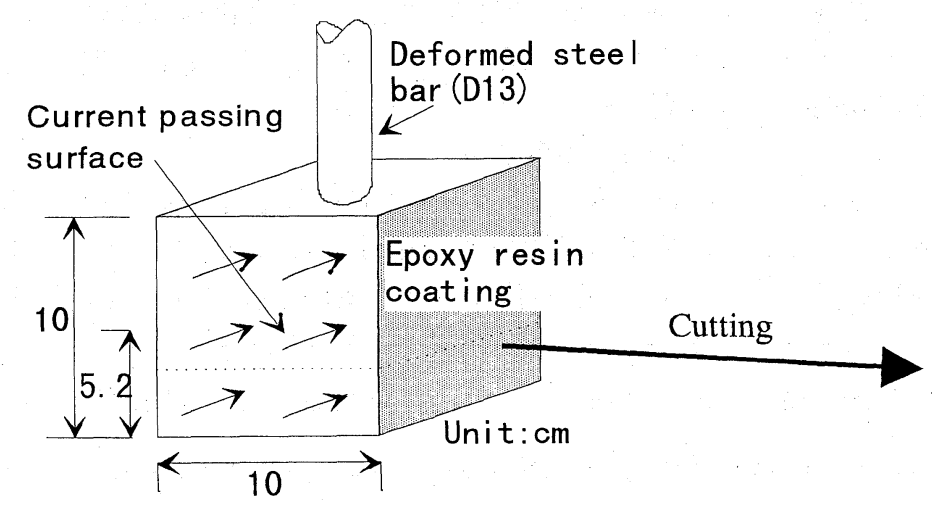

Fig. 1. Outline of specimen.
合電極として, 飽和塩化銀電極 $(\mathrm{Ag} / \mathrm{AgCl})$ を用い, 分 極抵抗は矩形波電流分極法（周波数 $0.1 \mathrm{~Hz}$, 電流量 100 $\mu \mathrm{A} ） に よ り$ 測定した.

\section{$2 \cdot 4$ 化学分析}

全塩分および可溶性塩分濃度分布測定の際の供試体の 切断方法を Fig. 2 に示す.

採取した試料は $0.15 \mathrm{~mm}$ ふるいを全量通過するまで粉 砕し，粉砕した試料 $1 \mathrm{~g}$ を 1 回の測定に用いた。測定は JCI-SC4 に準じて，全塩分量（硬化コンクリート中に含 まれる全塩分量）と可溶性塩分量（硬化コンクリート中 に含まれる $50^{\circ} \mathrm{C}$ の温水に可溶な塩分量）を測定した。

\section{3 デサリネーションによる脱塩効果}

\section{$3 \cdot 1 \mathrm{Cl}^{-}$の遊離・再分布}

デサリネーションを適用することによって, コンクリ 一ト中の遊離した $\mathrm{Cl}^{-}$は除去可能であるが, 特にコンク リート表面付近に未抽出塩分が残ることが報告されてい る. ${ }^{1}$ 処理終了後のコンクリート中において, 新たな濃度 平衡状態が形成され，固定化されていた $\mathrm{Cl}^{-}$の一部が遊 離した場合，再び鉄筋の腐食が始まる危険性が残されて いると同時に, 再度通電处理を施すことにより未抽出塩 分を除去できる可能性がある。

4 週間の通電直後と, 4 週間の通電後に 10 週間湿空静 置および 20 週間の促進中性化を行った供試体中の，全塩 分量打よび可溶性塩分量の分布状況を Fig. 3 に示す. Fig. 3 より, 4 週通電後 10 週間湿空静置を行っても, 4 週間通電直後と顕著な差は認められない.コンクリート が乾燥状態にあると，コンクリート中の細孔溶液を介し たイオンの移動が困難となることが予想される. 今回の湿 空状態は細孔溶液の蒸発を防ぐため, 比較的イオンの移 動が容易な条件と考元られるが, $\mathrm{Cl}^{-}$の遊離・再分布には さらに長期間の静置が必要であるものと予想される.

これに対して, 4 週間通電後 20 週間促進中性化を行っ た供試体は，コンクリート表面から $2 \mathrm{~cm}$ 程度の深さ位置 で塩分の濃縮現象が見られる。この供試体の中性化深さ は $13.7 \mathrm{~mm}$ であったことも勘案すると，コンクリートの 中性化により, 表面付近の $\mathrm{Cl}^{-}$が遊離し, コンクリート 内部方向へ移動したものと考えられる. $\mathrm{Cl}^{-}$量が $8.0 \mathrm{~kg} / \mathrm{m}^{3}$ の場合であるが, $4.0 \mathrm{~kg} / \mathrm{m}^{3}$ の場合も 同様の傾向を示した。

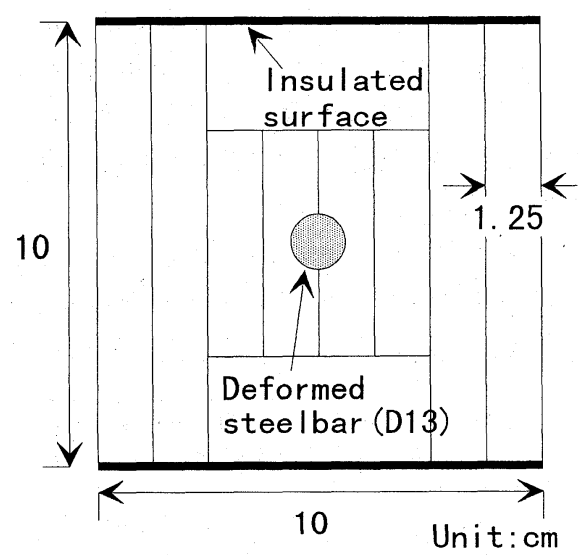

Fig. 2. Cutting for chemical analysis. 


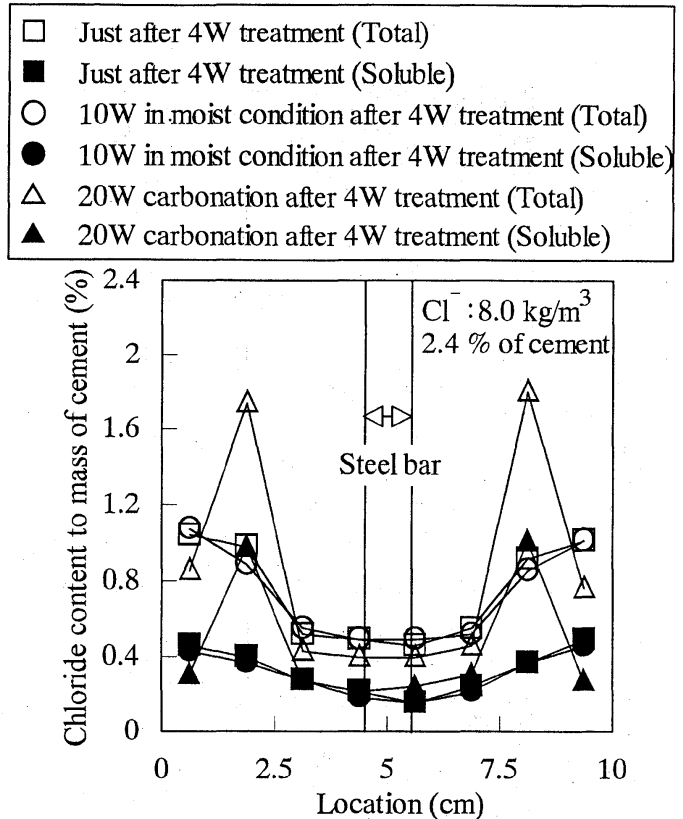

Fig. 3. Chloride distribution (4 weeks treatment).

\section{$3 \cdot 2$ 連続通電と断続通電の比較}

8 週間の連続通電と断続通電を施した供試体の全塩分 分布を Fig. 4 に示す. Fig. 4 より, 混入 $\mathrm{Cl}^{-}$量によらず, 通電処理の有無により明らかに塩分分布に違いが認めら れ，デサリネーションによる脱塩効果が確認できる。無 通電の供試体 (Control) を基準として計算した供試体全 体としての脱塩率は，連続通電の場合で, $\mathrm{Cl}^{-}$量が 4.0 $\mathrm{kg} / \mathrm{m}^{3}$ のとき, $58.5 \%, \mathrm{Cl}^{-}$量が $8.0 \mathrm{~kg} / \mathrm{m}^{3}$ のとき, $58.6 \%$ とほほ同程度となった。よって, 抽出塩分量は $\mathrm{Cl}^{-}$量が $8.0 \mathrm{~kg} / \mathrm{m}^{3}$ の場合の方が大きいことになる．ただし，従

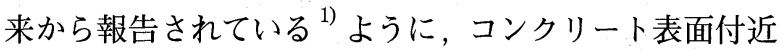
に未抽出塩分の残存が見られる。

10 週間湿空静置による断続通電と 8 週間連続通電を比 較すると，これらに顕著な差は認められない，前述した ように, 10 週間湿空静置では全塩分および可溶性塩分の 分布に変化がなかったことが原因と考えられ，この程度 の断続通電は脱塩率向上にほとんど寄与しないと言える.

これに対して，20 週間の促進中性化を行った場合と 8 週連続通電の場合を比較すると，断続通電を行うことに より連続通電の場合よりも，コンクリート表面付近およ び鉄筋近傍の塩分を低減できていることがわかる。これ は，前述したように通電処理後の促進中性化により固定 化されていた $\mathrm{Cl}^{-}$が遊離したことに起因しているものと 考えられる。すなわち，コンクリート中の遊離した $\mathrm{Cl}^{-}$ の割合が増加することにより，供試体全体としての $\mathrm{Cl}^{-}$ の輸率が大きくなったものと考えられる．ただし，この 場合, 中性化層よりも鉄筋側に塩分の濃縮層が形成され るため，供試体全体としての脱塩効果が著しく向上した とは判断できないであうう。

\section{$3 \cdot 3$ 通電処理後の可溶性塩分量分布}

コンクリート中の鉄筋腐食に直接的に関与するのは, イオンの形で遊離した $\mathrm{Cl}^{-}$であり, 通電処理後の $\mathrm{Cl}^{-}$が どの様な形態でコンクリート中に存在するかを把握する
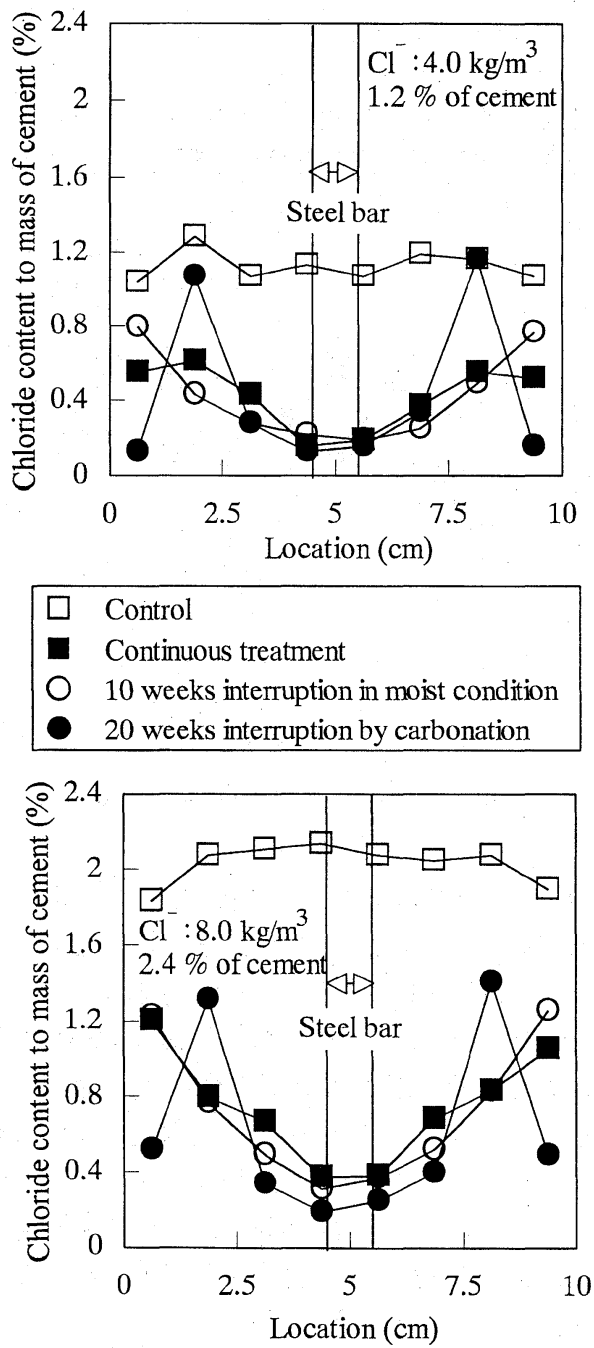

Fig. 4. Chloride distribution (8 weeks treatment).

ことは，処理後の鉄筋腐食挙動を考える上で非常に重要 であると考えられる。

8 週間通電処理後の全塩分量に対する可溶性塩分量の 割合分布を Fig. 5 に示す。なお，Fig. 5 は，混入 $\mathrm{Cl}^{-}$量 が $8.0 \mathrm{~kg} / \mathrm{m}^{3}$ の場合である。この図によると，無通電の 供試体では，可溶性塩分の全塩分に対する割合は約 70\% であるが，通電处理を行うことにより，全体的に可溶性 塩分の割合が減少している。特に鉄筋の近傍では $40 \%$ か ら $50 \%$ 程度まで減少しており，デサリネーションにより 遊離塩分が優先的に抽出されたことを示している.

一方, Fig. 4 によると, 8 週間の通電処理により鉄筋 近傍の全塩分量はセメント重量に対して $0.4 \%$ 程度かそれ 以下まで減少しているにも関わらず，Fig. 5 に示すよう に依然として鉄筋近傍に可溶性塩分が存在している。一 般に固定塩分はセメント重量の $0.4 \%$ 程度であると言われ ている ${ }^{3)}$ が，このレベル以下であっても遊離した $\mathrm{Cl}^{-} か ゙$ 存在することが報告されている. 示すような通電処理によるコンクリート中の $\mathrm{pH}$ 上昇の 可能性も考えられる.

デサリネーション適用時の鉄筋近傍では, カソード反 応によって大量の $\mathrm{OH}^{-}$が生成して打り, $\mathrm{pH}$ が 13.6 程度

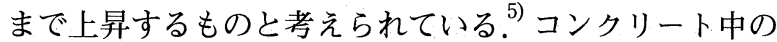



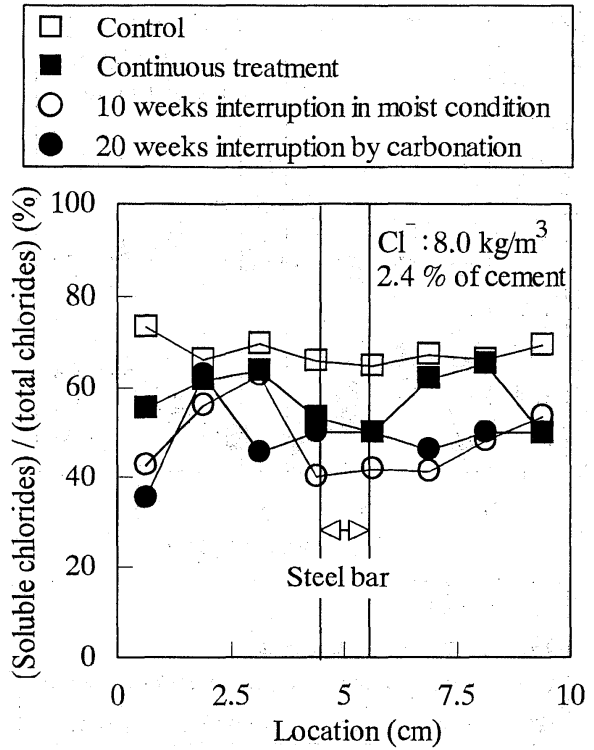

Fig. 5. Soluble chloride to total chloride ratio distribution.

$\mathrm{pH}$ が一般的な值であるる 12.6 程度よりも高い場合に，固 定される $\mathrm{Cl}^{-}$の割合が減少することが報告されており， この場合も, $\mathrm{pH}$ の上昇に伴い, 固定されていた $\mathrm{Cl}^{-} か ゙$ 遊 離した可能性がある.'これに対して，鉄筋腐食は $\mathrm{OH}^{-}$濃 度に対する $\mathrm{Cl}^{-}$濃度がある一定割合以上となるときに発 生すると言われており ${ }^{8)}$ 今後はこの様な観点も含めて, デサリネーション適用後の鉄筋腐食挙動を考えていく必 要があろう。また，本実験で測定された可溶性塩分と実 際に細孔溶液中に存在する遊離した $\mathrm{Cl}^{-}$の対応関係も確 認の必要があるものと考えられる.

\section{4 電気化学的特性值による処理後の耐久性評価}

\section{$4 \cdot 1$ 自然電位の経時変化}

$4 \cdot 1 \cdot 1$ 塩水浸漬 8 週間の連続通電を行った供試 体について, 通電処理終了後の鉄筋自然電位を測定した. 処理後に塩水浸漬を行った時の自然電位経時変化を Fig. 6 に示す。図中の折れ線はそれぞれ 1 体の供試体に対応 しており，領域の区分はASTM の判定基準に，JCIによ り規定された海水中コンクリート構造物の防食基準 ${ }^{9)}$ 参考值として加えたものである.

混入 $\mathrm{Cl}^{-}$量が $4.0 \mathrm{~kg} / \mathrm{m}^{3}$ の場合, 無通電の供試体 (Control) は浸漬開始直後から不確定領域の電位で推移し，比較的 緩やかな腐食傾向を示しているが，浸漬日数が 500 日を 越えた付近から電位はさらに卑変し，腐食領域 (Corrosion) に入っている。これは，コンクリート表面 から浸透した $\mathrm{Cl}^{-}$が鉄筋位置に到達したことによるもの と推測される。これに対して, 通電処理を行った供試体 (Treated) は, 塩水浸漬開始直後においては, 通電処理 によるカソード分極の影響で，鉄筋電位は防食領域 (Protection) にあるが，その後の酸素供給による不動態 被膜形成に伴い, 電位は非腐食領域 (Non-corrosion) 付 近まで貴変する。この状態で無通電供試体よりも貴な電 位となり，デサリネーションによる鉄筋腐食環境改善を 示しているものと考えられる．さらに，浸漬日数が 700 日を越えた付近から電位は著しく卑変しており，これは
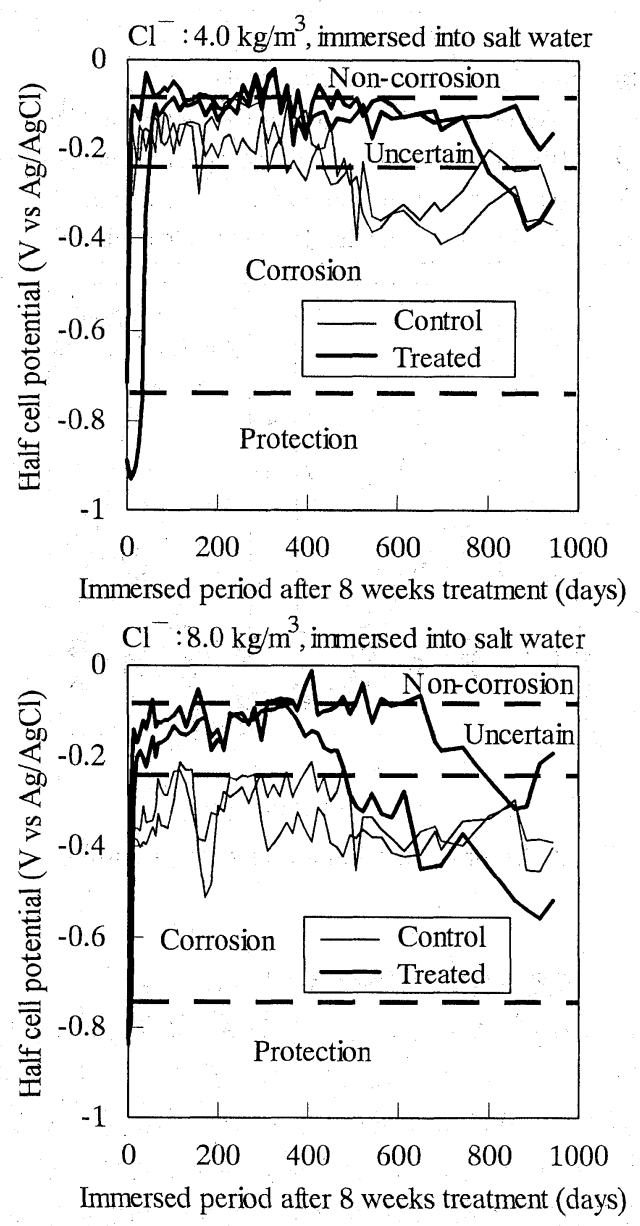

Fig. 6. Change of half cell potential after desalination (Immersion into salt water).

外部からの $\mathrm{Cl}^{-}$の浸透によるものと考えられる.

塩水浸漬を開始した時点において, 通電処理を行った 供試体中の $\mathrm{Cl}^{-}$量は無通電の供試体中の $\mathrm{Cl}^{-}$量よりも小 さいことから，鉄筋近傍の $\mathrm{Cl}^{-}$量が腐食開始の臨界值に 達するまでの期間は通電処理を行った場合の方が長くな ったものと考えられる。また，コンクリート表面からの $\mathrm{Cl}^{-}$浸透現象が濃度勾配を駆動力とする拡散現象と考え ると, 無通電の供試体と比較して, 通電処理を行った場 合の方がコンクリート内部の $\mathrm{Cl}^{-}$が抽出されている分だ け $\mathrm{Cl}^{-}$の濃度勾配が大きくなり，拡散駆動力も大きくな るものと予想されるが，実際には通電処理を行った供試 体の方が $\mathrm{Cl}^{-}$の浸透速度が小さくなることが報告されて いる. ${ }^{1)}$ これらの理由により，デサリネーションを適用し た供試体の方が電位の卑変が遅れたものと考えられる.

混入 $\mathrm{Cl}^{-}$量が $8.0 \mathrm{~kg} / \mathrm{m}^{3}$ の場合, 無通電の供試体は浸 漬開始直後から腐食領域の電位で推移し，コンクリート 表面からの $\mathrm{Cl}^{-}$浸透の影響は明確ではない.これに対し て，通電処理を行った場合には，供試体によりばらつい ているが，浸漬日数が 400 日〜 500 日程度までは鉄筋防 食効果が持続していたものと推測される. $\mathrm{Cl}^{-}$量が 4.0 $\mathrm{kg} / \mathrm{m}^{3}$ の場合よりもコンクリート中の残留 $\mathrm{Cl}^{-}$量が大き いために，鉄筋防食効果の持続期間が短くなったものと 考えられる。 


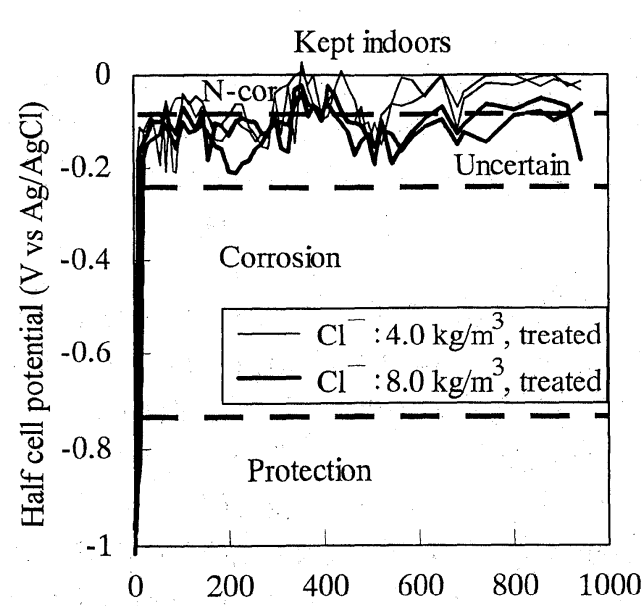

Kept period after 8 weeks treatment (days)

Fig. 7. Change of half cell potential after desalination (Keeping indoors).

$4 \cdot 1 \cdot 2$ 室内静置 処理後に室内静置を行った供試 体の自然電位経時変化を Fig. 7 に示す. これらの供試体 はコンクリート表面からの $\mathrm{Cl}^{-}$浸入がないために, 腐食 反応が再発するのは，コンクリート表面付近に残存する 未抽出塩分が鉄筋方向に再拡散する場合に限られる. ま た, 水分の供給もないために, コンクリート内部は徐々 に乾燥し，イオンの移動や鉄筋腐食セルの形成が難しく なるものと考えられる.

以上のような比較的防食性の高い環境条件を反映し て, 通電処理を行った供試体の鉄筋自然電位は, 処理直 後の防食領域から貴変して非腐食領域や不確定領域の貴 な電位を推移している.

この結果より, 通電処理終了後に適切な表面処理を行 うことにより, 外部からの腐食因子浸入を防ぐとともに， コンクリートを乾燥させることが可能であれば，処理後 の長期的な耐久性が期待できるものと考えられる。 今後 は撥水型の表面処理材等の活用を検討する必要があろう.

\section{$4 \cdot 2$ 分極抵抗の経時変化}

8 週間の連続通電を行った供試体について, 通電処理 終了後に自然電位と併せて分極抵抗值を測定した。分極 抵抗 $R_{p}$ は一般に次式に示すように腐食電流 $I_{c o r r}$ と関連 する值である. ${ }^{11)}$

$$
I_{\text {corr }}=\frac{\beta_{a} \cdot \beta_{c}}{2.303\left(\beta_{a}+\beta_{c}\right)} \cdot \frac{1}{R_{p}}=K \cdot\left(\frac{1}{R_{p}}\right)
$$

ここで, $K$ は金属の種類や環境条件によって決まる定 数， $\beta_{a}$ および $\beta_{c}$ はそれぞれ，アノードおよびカソードの ターフェル勾配である. 式 (1) に示されるように，分極抵 抗が大きいほど腐食電流量または腐食速度は小さくなる。

自然電位は「その時点での鉄筋腐食状況を推定する指 標」であり,これに対して, 分極抵抗は「微弱電流を強 制的に印可したときの反応抵抗值」であり，「腐食速度を 推定する指標」という点で自然電位とは異なる意味合い を持っている。 また, 腐食反応は, アノード反応とカソ 一ド反応の組み合わせで発生し, 分極抵抗 $R_{p}$ とアノード 反応抵抗 $R_{a}$ 打よびカソード反応抵抗 $R_{c}$ の関係は式 (1) から導かれる次式で表すことができる。
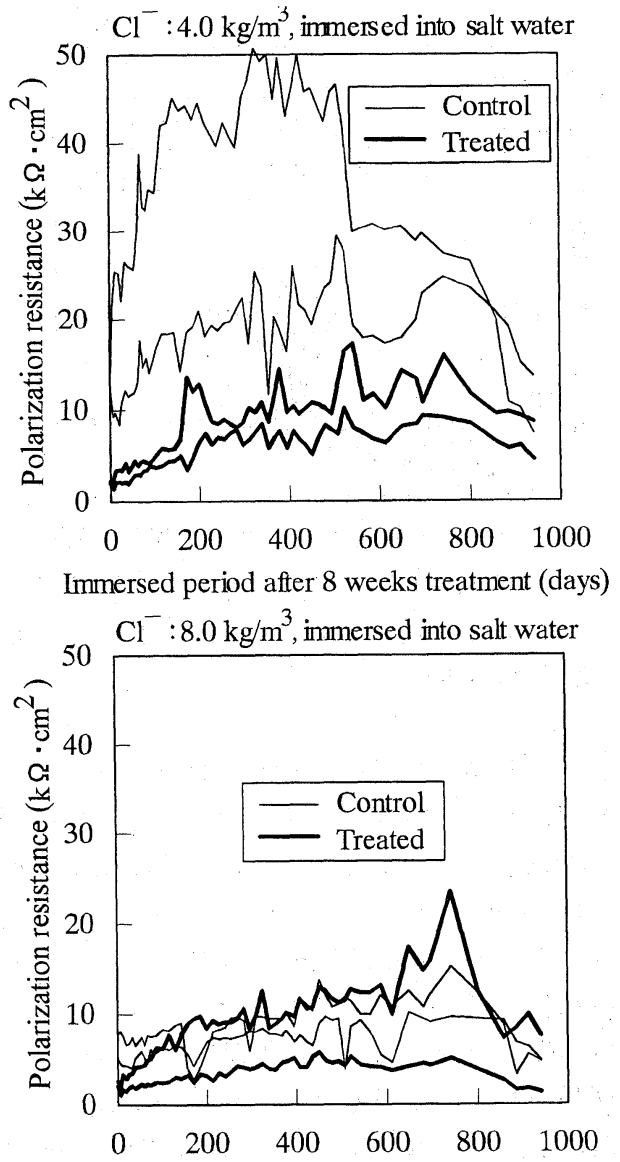

Immersed period after 8 weeks treatment (days)

Fig. 8. Change of polarization resistance after desalination (Immersion into salt water).

$$
\frac{1}{R_{p}}=\frac{1}{R_{a}}+\frac{1}{R_{c}}
$$

すなわち, 分極抵抗はアノード反応とカソード反応, 両腐食反応の起こり易さを併せて表現する指標と言える.

$4 \cdot 2 \cdot 1$ 塩水浸漬 処理後に塩水浸漬を行った時の 分極抵抗経時変化を Fig. 8 に示す. 図の縱軸には分極抵 抗測定值と鉄筋表面積の積をとっている. Fig. 8 による と, 混入 $\mathrm{Cl}^{-}$量が $4.0 \mathrm{~kg} / \mathrm{m}^{3}$ の供試体の方が $8.0 \mathrm{~kg} / \mathrm{m}^{3}$ の 場合より，全体的に大きな分極抵抗を示しており，この 点では従来通りの解釈が成立するが，通電処理を行った 供試体は腐食環境が改善されているにも関わらず，小さ な分極抵抗を示していることがわかる. 特に通電处理終 了直後の分極抵抗は非常に小さく, $1.0 \mathrm{k} \Omega \cdot \mathrm{cm}^{2}$ 程度と なって打り，この後緩やかに経時的な増大傾向を示して いる.

通電処理を行った場合には，コンクリート中の鉄筋全 体を大きくカソード分極するため，アノード反応抵抗は 大きくなるが，カソード反応抵抗は極端に小さいという， 特殊な電気化学的状態となることが考えられる．このた め，両反応抵抗を考慮して全体で分極抵抗として表現す ると，非常に小さな值となってしまうものと考学られる. 実際に，コンクリート中の 2 本の鉄筋をそれぞれアノー ドとカソードにしてマクロセル腐食を発生させた後に， それぞれの鉄筋の分極抵抗を測定したところ，カソード 側鉄筋は全く腐食していなかったのにも関わらず，分極 


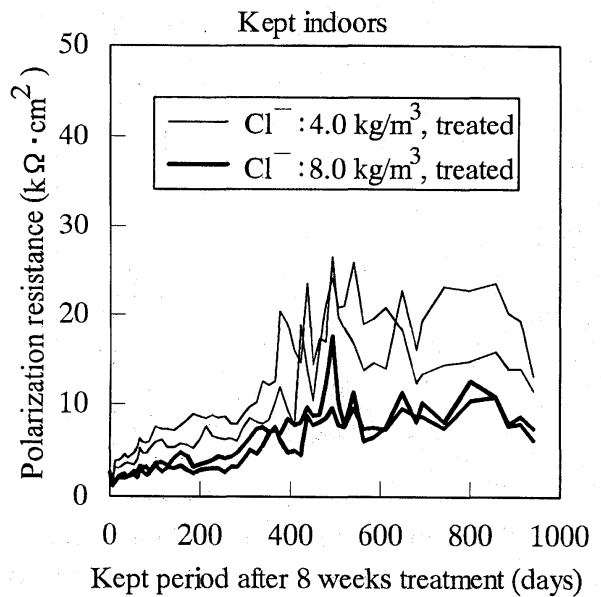

Fig. 9. Change of polarization resistance after treatment (Keeping indoors).

抵抗はアノード側鉄筋の測定値と同程度となったとの実 験結果も報告されている. ${ }^{12)}$ デサリネーションを適用した 場合の分極抵抗については，上記のような状態を考慮し て評価を行う必要があろう。

Fig. 8 によると, 通電处理終了直後に非常に小さかっ た分極抵抗値はその後に徐々に増大している。これは， 自然電位の場合と同様に，通電处理による電場の影響が 徐々に緩和されていく現象に対応しているものと考えら れる。ただし，自然電位の場合には，処理終了後の電位 は無通電の供試体よりも貴な電位まで上昇し，デサリネ ーションによる腐食環境改善効果が確認できたが, 分極 抵抗の場合には，通電处理を行った供試体の值は経時的 に増大はするものの，無通電の供試体の值を大きく上回 るには到っていない。 このことより，自然電位では現れ ないデサリネーションによるカソード分極の影響が何年 もの長期間にわたって存在する可能性もあるが，この点 については実際の鉄筋腐食状況と併せて今後さらに検討 する必要がある。

また，混入 $\mathrm{Cl}^{-}$量が $8.0 \mathrm{~kg} / \mathrm{m}^{3}$ の通電処理を行った供 試体 2 体は分極抵抗値がばらついており，1体は順調に 経時的な分極抵抗の増大が見られるが，もう1体は小幅 な増大に留まっている．Fig. 6 で早期に自然電位が卑化 している供試体が後者であり，この供試体は通電処理終 了直後から既に腐食傾向が強く，そのために早期に腐食 状態が実現したものと考えられる。この様に，自然電位 と分極抵抗を組み合わせることにより，鉄筋の腐食・防 食状況に関するより多角的な情報を得ることができる可 能性がある。なお， $\mathrm{Cl}^{-}$の浸透によると考えられる分極 抵抗の低下現象も見られ，元の開始時期は，自然電位の 卑化が開始した時期とほぼ同じである。

$4 \cdot 2 \cdot 2$ 室内静置 処理後に室内静置を行った供試 体の分極抵抗経時変化を Fig. 9 に示す. $4 \cdot 1 \cdot 2$ 項で述 べたように，比較的防食性の高い環境条件であることか ら, 分極抵抗は徐々に増大しており, 自然電位の測定結 果と高い相関を示している。また，混入 $\mathrm{Cl}^{-}$量が $4.0 \mathrm{~kg} / \mathrm{m}^{3}$ の場合の方が $8.0 \mathrm{~kg} / \mathrm{m}^{3}$ の場合より, 大きな 分極抵抗を示して抢り，腐食環境の改善効果が大きかっ
たことを示している.

ただし，静置期間が 800 日を越えた付近から分極抵抗 の低下が見られ，自然電位ではまだ高い電位を維持して いるが，今後，鉄筋腐食が発生する可能性も考えられる.

\section{5 結 論}

本研究結果をまとめると次のようになる。

（1）鉄筋表面積に対して $5.0 \mathrm{~A} / \mathrm{m}^{2}$ で 8 週間の通電処 理を行ったところ, 無通電供試体に対して約 6 割の $\mathrm{Cl}^{-}$ が抽出できた。特に鉄筋近傍で脱塩効果は大きかったが， コンクリート表面付近に未抽出塩分が残った。

（2） 4 週間通電後 10 週湿空静置を行った供試体は， $\mathrm{Cl}^{-}$の遊離は見られず, 断続的通電处理の影響は見られ なかった。これに対して, 4 週通電後 20 週促進中性化を 行った供試体では, $\mathrm{Cl}^{-}$の移動・濃縮現象が見られ，断 続的通電処理により，コンクリート表面付近および鉄筋 近傍の脱塩効果が若干向上した。

（3） 8 週間の連続通電後に塩水浸漬を行ったところ, 自然電位拉よび分極抵抗の経時変化より，デサリネーシ ョンによる鉄筋防食効果が確認された。 また，その効果 は混入 $\mathrm{Cl}^{-}$量が小さい方が大きかった。

（4） 8 週間の通電処理後に室内静置を行ったところ, 自然電位打よび分極抵抗の経時変化より，処理後 900 日 程度経過した段階で鉄筋防食効果が維持されていること が確認された。これより, 通電処理後の適切な環境設定 により，デサリネーションの効果を長期間持続させるこ とが可能であることが明らかになった。

\section{参 考 文 献}

1）上田隆雄, 小川智広, 宮川豊章, 芦田公伸, コンクリート 構造物の補修工法に関するシンポジウム論文報告集, p.43 (1996).

2）岸谷孝一, 小林一輔，樫野紀元，宇野祐一，コンクリート 工学年次論文報告集， 13，601 (1991).

3）大即信明，樫野紀元，片脇清士，小林明夫，宮川豊章， “コンクリート構造物の耐久性シリーズ＼cjkstart塩害 (I)”(1986) 技報堂出版。

4) 米澤敏男, V. Ashworth, R. P. Procter, コンクリートエ 学年次論文報告集, 10，475（1988）.

5）芦田公伸，石橋孝一，コンクリート工学年次論文報告集, 16, 823 (1994).

6) G. K. Glass and N. R. Buenfeld, Corrosion Science, 39, 1001 (1997).

7) J. Tritthart, K. Pettersson and B. Sorensen, Cement and Concrete Research, 23, 1095 (1993).

8) D. A. Hausmann, Materials Protection, 6, 19 (1967).

9）(社）日本コンクリート工学協会, “海洋コンクリート構造物 の防食指針（案)”(1990)。

10）横田 優, 佐々木晴敏, 福手 勤, コンクリート工学年次 論文報告集，14，849（1992）。

11) M. Stern and A. L. Geary, Journal of the Electrochemical Society, 104, 56 (1957).

12）横田 優, 土木学会第 52 回年次講演会講演概要集, 5 , 668 (1997). 